\title{
The Season
}

In this chapter I want to walk the reader through Kedarnath as it felt in 2007 and 2008. As I do so I direct the eye and imagination of the reader in several specific directions. First, I emphasize how diverse experiences of Kedarnath were consistently produced through eco-social engagements with the place as a whole rather than solely focused on a single location there, such as the temple. Second, I illustrate how Kedarnath functioned as a point of overlap for different forms of transregional Hindu pilgrimage and tourism as well as region-specific and sometimes valley-specific Garhwali matters. Third, I foreshadow events and trends that, in post-2013 hindsight, were revealed as critical vectors. Kedarnath was in the process of recent and rapid change because of the growing numbers of yatris and the pace of recent commercial development. The interdependent levels of energy, devotion, capital, anxiety, environmental stress, and debt related to Kedarnath were rising. There was a sense of a rapidly expanding and swollen bubble.

I begin, after a brief sketch of the rhythms of the season, with extended presentations of two examples that highlight the ways that different locations in and around Kedarnath village served as focal points for human and divine attention: the visit of a local Kedarnath valley deity who wandered over the entire Kedarnath end-valley (thereby introducing the reader to the layout of Kedarnath and the surrounding locale) and the distinctive aspects of the ritual of the ghee massage (Hindi: ghee malish) of the linga performed by devotees in the inner sanctum of the temple. I then focus on vignettes that illustrate themes necessary for understanding the Kedarnath of 2007 and 2008: the intensity of the high season, bhakti, weather, labor, livelihood, nature tourism, trekking, Garhwali nature spirits, and the relationship of divine shakti to the natural Himalayan landscape. I conclude 
by recalling events that in retrospect felt like previews, foreshocks as I call them, of what would happen in 2013. Pervasive in all of these moments of description is my commitment to attend to the experiential weight of the underlying eco-social interconnectedness of these different times, practices, experiences, modalities, forces, and organic and inorganic entities.

\section{THE TIMINGS OF THE SEASON}

An advance party of Samiti, public works, police, and military employees proceeded to Kedarnath several weeks before the season began. They confirmed that the path was passable and that enough snow had melted to allow access to the buildings. Friends told me that there had been years when they would use the notyet-electrified electric lines as handrails because the snow was so high when they made the preseason ascent. Phone and electrical wires had to be reinstalled and pipes for water reinserted into the ground that had been removed at the end of the previous season. The season began, according to custom, with the three-day procession from Ukhimath to Kedarnath of the traveling form (Hindi: utsav murti) of Kedarnath-Shiva, carried in a palanquin (Hindi/Garhwali: doli). The departure date of the procession varies for astrological reasons but is usually near or on the third lunar day of the waxing fortnight of the month of Baisakh (Hindi: akshay tritiya of the shukla paksh of Baisakh). In 2007, the Kedarnath doli left Ukhimath on April 27 and arrived on April 30, with the doors of the temple opening the next morning. Bhairavnath was worshipped in Ukhimath the evening before departure and sent ahead to prepare the way and ensure a safe procession and safe opening. Bhupendra and I walked with the doli.

The arrival of the doli in Kedarnath is the key that activates the energy of this place that has lain quiescent during the winter months. Once the doors are open and Bhairavnath has been officially worshipped in Kedarnath in his Bhukund Bhairavnath form, the season begins. During the first approximately six weeks of the season in 2007 and 2008, in the high season, the area was bursting at the seams, and the Gaurikund-Kedarnath footpath became a continuous stream of yatris, often with over ten thousand visitors passing through the place each day. The exact duration of the high season changes from year to year because of the permutation of several factors: the date the temple opens, the beginning of school holidays and vacations for salaried employees, and the onset of the monsoon. In a "normal" year the monsoon will not begin in Garhwal until sometime in July. Once the monsoon begins in the mountains it is not a good time to travel from the plains-the chance of landslides affecting road travel is too great and the plains have started to cool off. In 2007 the high season was perhaps a bit longer than most; one contributing factor was that Jyet (May-June), the month following Baisakh, was longer than usual in 2007. During the high season at Kedarnath, everything is more expensive and 


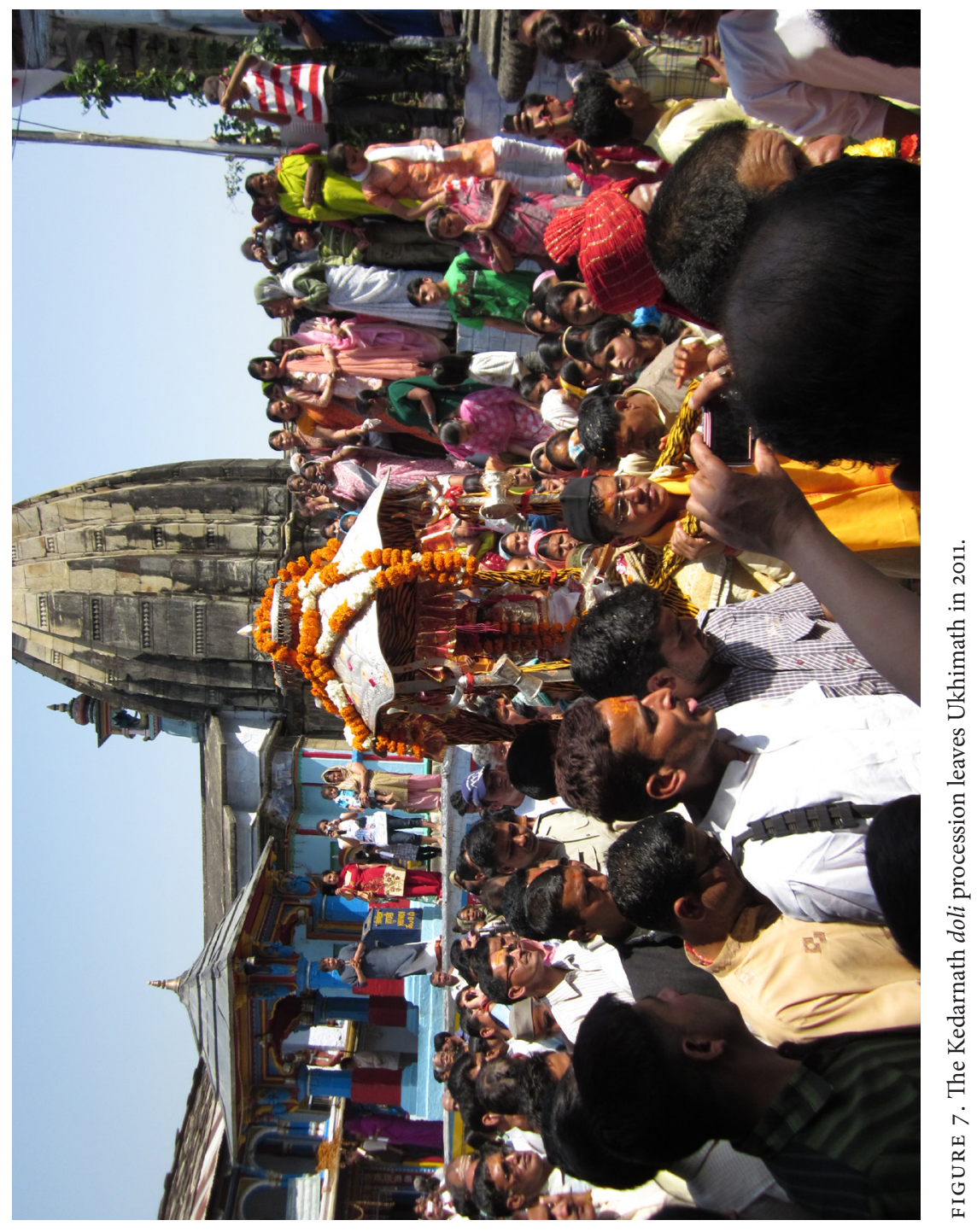




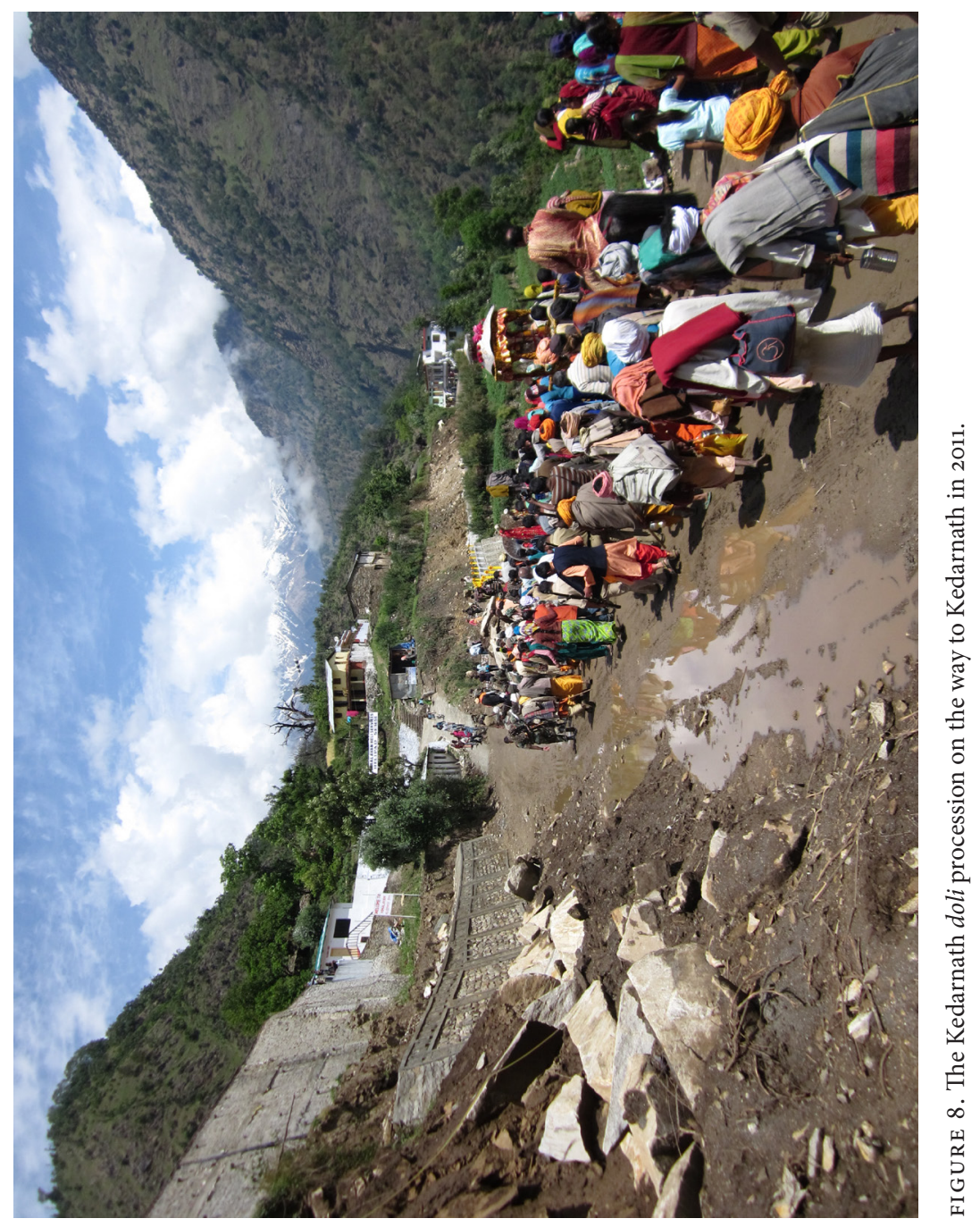


people are in a hurry. This is also when, correspondingly, the resident population of Kedarnath is highest. Many tirth purohits will come for this period and then depart, for various reasons (e.g., a schoolteacher who is also on his holiday).

The high season in 2007 ended around the end of June and the monsoon began. Monsoon season in the Kedarnath valley means that the roads will inevitably be blocked by landslides at least several times; in Kedarnath these occasions were apparent because the flow of yatris would suddenly decrease. The end of June and July and the first part of August (the months of Ashadh and Shravan) were the slowest times in Kedarnath; many locals who did stay for the entire season took the opportunity for a quick trip home then. The month of Shravan, Shiva's month, began in 2007 in the middle of July. The time of the monsoon is often when Garhwalis will themselves go on yatra within Garhwal. This was also when herders began to arrive in the area around Kedarnath with sheep, goat, and buffalo herds; before then only powdered milk was usually available. Bhukund Bhairavnath was the focus of devotion during this time for locals. Shravan was when Kedarnath valley locals who worked between Gaurikund and Kedarnath themselves came to Kedarnath, first entering the temple and then proceeding up to Bhukund Bhairavnath to offer him oil and thick flatbread cooked with cane sugar/molasses water (Garhwali: rot; Hindi: roti).

In the eight to ten years preceding 2013, during the latter half of Garhwali Shravan, kavad groups began coming to Kedarnath (usually from Gangotri) as an extension of the non-Garhwali kavad festival that centered on doing a barefoot yatra, bearing pots of water, known as kavad, to Haridwar and the Neelkanth Mahadev temple near Rishikesh and that involved millions of devotees per year. Several tirth purohits also told me that farmers would often come on yatra during the monsoon (or more technically, when the monsoon was happening for them), because little agricultural work could be done during that time. In stark contrast to the intense crowding of the high season, during July and August (and even later) at Kedarnath in 2007 it was possible to spend hours at a time in the inner sanctum of the temple. There was time for locals to play cricket on the floor of a side valley behind Bhukund Bhairavnath to the east.

Just after the beginning of Bhadon in mid-August of 2007, the Samiti sponsored an eleven-day recitation of the Sanskrit text of the Shiva Purana, beginning on August 17. Following close on the heels of the ending of the Shiva Purana in 2007 was the local festival of Bhatuj, as far as I know celebrated under this name only at Kedarnath and a few other temples in the Kedarnath valley area. Preparations began on August 31, and the final elements of Bhatuj worship were done in the early morning on September 1. Bhatuj is a local form of the common new grain festival known in Hindi as annakut. Kedarnath valley locals, especially teenagers, descended on Kedarnath in crowds for this festival, and it felt to me like a mela, although I did not hear anyone use this word. Specially chosen tirth purohits 
from the five villages of Ukhimath prepared a large quantity of rice that they then shaped into bricks and placed on top of the linga in the temple to form a pyramidal shape. The temple then opened early in the morning for this special darshan. ${ }^{1}$ There was also a mela at Triyugi Narayan in September, one of the most important in the region.

By early September the monsoon had given way to about a month and a half of beautiful clear weather, the best time of the year for walking in the Garhwal Himalaya. Late September and October saw greater and greater numbers of Bengalis in Kedarnath who were taking advantage of the long holidays afforded by Durga Puja in West Bengal to come to the Himalaya. ${ }^{2}$ As October advanced the weather began to turn cold and locals began to leave except for the core group whose custom it was to see out the entire season. When Bhupendra and I briefly left Kedarnath to visit Madmaheshwar the only other visitors in Madmaheshwar at the time were Bengalis and a local village on yatra with their devta (deity).

The season in Kedarnath ends on Bhaiya Duj (Bhai Dooj), a festival that falls on the last day of Diwali. The Kedarnath doli typically leaves in the morning and takes two days and three nights to return to Ukhimath. On the penultimate day, the distinguished political and religious figures and devotees whose custom it was to attend the opening and closing of the temple arrived. The ranks of police and military grew as they did what was necessary to secure Kedarnath for the winter. On the final morning, the military ran its food kitchen for all those still remaining in the village. The night before departure, Kedarnath-Shiva received samadhi puja, an elaborate procedure that involved the covering of the linga with numerous layers of bilva leaves, ash, and fruit, as if tucking Shiva in for the winter. In the morning, the Samiti prepared the doli for departure. It emerged from the temple around eight in the morning, and representatives of the Samiti locked the temple. The drums and bagpipes of the Garhwali military band sounded, along with the Garhwali drums that accompany the deity on deity processions in Garhwal. Snow had begun to fall in Kedarnath several days before the end of the season. Combined with the sunshine of the morning, this meant that the first several kilometers of the journey were over a footpath covered with melting ice. With the departure of the doli from Kedarnath at the end of the season, the area, even more so than during the season, officially became the province of Bhairavnath. Decades ago there was a famous renunciant named Phalahari Baba, memorialized at several different locations in Kedarnath, who reportedly used to spend the entire winter inside a single building, but in 2007 to the best of my knowledge no humans spent the winter. During the first five years after 2013 the offseason has been different and nontraditional: construction workers and heavy machinery have often stayed on in Kedarnath during much of the winter so that reconstruction could proceed and Kedarnath could be as ready as possible for the next high season. 
The visits of Garhwali deities in their palanquins have been an important feature of the season in Kedarnath, although this would not necessarily have been apparent to short-term visitors. Most of the time Kedarnath feels like a supraregional and Pan-Hindu (to use Surinder Bhardwaj's classification) North Indian tirtha located in the Himalaya (Bhardwaj 1973). The lingua franca of Kedarnath is Hindi, with many tirth purohits also speaking a bit of the different languages or dialects of their specific patron communities (Gujarati, Punjabi, Sindhi, Bhojpuri, Marathi, Marwari, etc.). Hindi devotional songs and Sanskrit verses play over the temple loudspeakers, occasionally interspersed with the words in Hindi of famous reciters and expounders (Hindi: kathavacak) of Puranas and the Ramayana. Video discs of the Shiva Purana, the Char Dham Yatra, the Panch Kedar, and the twelve jyotirlinga can be heard when there is electricity, and most of the pamphlets and literature are written in Hindi, though one can also find Gujarati, Bengali, Tamil, Telugu, and Nepali. In the main, Kedarnath is more a Hindi place than a Garhwali place. The yatras of Garhwali deities, known as deora or devra (short for devta-yatra or "deity-yatra"), are certain moments in the season when in contrast Kedarnath becomes an intensely Garhwali place, a place animated by (to reference again Bhardwaj's taxonomy) regional, subregional, and sometimes even local concerns. With this general framing in mind I now describe the deora of Nala Devi (also known as Lalita Mai) to Kedarnath on August 29-30, 2007. In the context of this chapter a description of her visit also functions as an introductory tour of Kedarnath and the Kedarnath-end valley as conducted by a local guide that shows how for some the power and importance of Kedarnath spread out beyond the temple and across the Kedarnath valley as a whole.

As with many deoras, we could see the Nala Devi procession and hear the sound of her accompanying dhol and damaun drums before she actually came over the bridge. ${ }^{3}$ Nala Devi came through the horse area and over the bridge marking entry into Kedarnath proper a bit before five in the afternoon on August 29. She traveled as many Garhwali deities travel: as a collection of murtis (Hindi: material form of a deity, in Garhwal often found in the form of a metal mask) inside a doli suspended between two poles resting on the shoulders of two or four barefooted men. ${ }^{4}$ Nala Devi, by which I mean the doli containing the forms of her material presence, was swathed in numerous textile adornments, garlands, and dozens of scarves.

Much of the resident population of Kedarnath had turned out to welcome her as she crossed the bridge. Officials of the Kedar Tirth Purohit Association and members of the Samiti welcomed her with garlands and with the chanting of mantras. As with many Garhwali deities on the move, her doli was mobile in three dimensions, bending and shaking and bowing. The movement of those who have the doli on the shoulders is frequently, when the deity is in such an active mode, 
jerky and somewhat unstable, as if she is pulling them or forcing them to go in a particular direction. The Kedarnath doli, by contrast, does not move in this way, and its progress is statelier. Nala Devi proceeded with this kind of motion down the steps to the small ghat (Hindi: stepped bathing area) on the bank of the Mandakini river. She bowed repeatedly to the river until four or five people began to bathe her by dipping vessels in the water and pouring them over the doli.

She then came up through the main bazaar, thronged on all sides with people. Local women were throwing flowers and rice, as they do on many auspicious occasions when a devta is present, and some were tying on scarves to the doli. People were shouting “Jai Kedarnath, Jay Ganga, Jay Lalita Mai." She turned into the lane for the Udak Kund, the enclosed water tank whose water yatris are often told is especially efficacious for the destroying of negative karma, and made reverence at the small adjoining Navadurga Devi temple. The Navadurga temple is usually a devotional focus only during specific, Devi-related times such as the festival of Navaratri. With the exception of her powerful river-forms, Kedarnathbased forms of Devi do not, with the exception of Navaratri and the occasional devotional attentions of someone who is a particularly ardent devotee of the Goddess, attract a significant amount of human ritual attention. Devi is much more prominently present in her form of Gauri-Parvati, in Gaurikund, at the trailhead for the ascent to Kedarnath. However, numerous Garhwali devis, or forms of the Goddess (along with other deities), visit Kedarnath on deora. Nala Devi then went back to the main road of the bazaar and proceeded into the courtyard of the temple. Nala Devi possessed her designated vehicle (Garhwali: naur), who made motions of request with his hands and body and was given water.

Thus attended with devotion, spectacle, and fanfare, Nala Devi entered the courtyard, performed one parikrama (Hindi: circumambulation) of the temple, and after bowing to the Ganesha who guards the door of the Kedarnath temple, was taken off the shoulders of her bearers and placed in front of the stillclosed door of the temple, where she received a small puja. When the temple opened for shringar darshan, Nala Devi was picked up and entered into the inner sanctum. She, in the form of the murtis carried inside the doli, was lifted from her doli and placed onto a niche in the back wall of the inner sanctum immediately behind the linga. Nala Devi would remain there until the next morning when it was time for puja.

There is a theatrical aspect to the arrival of Garhwali deities in Kedarnath, and specifically in the temple courtyard. The devta becomes more active as it approaches the temple, and the drumming quickens. Often the deora yatris begin to dance one of the circular dances that are often claimed as a hallmark of Garhwali culture, and frequently several people (women and men) become possessed. I was able to observe such moments in 2007 perhaps a dozen times. When a deity enters the courtyard, hundreds of locals stop their Kedarnath-related business with yatris 


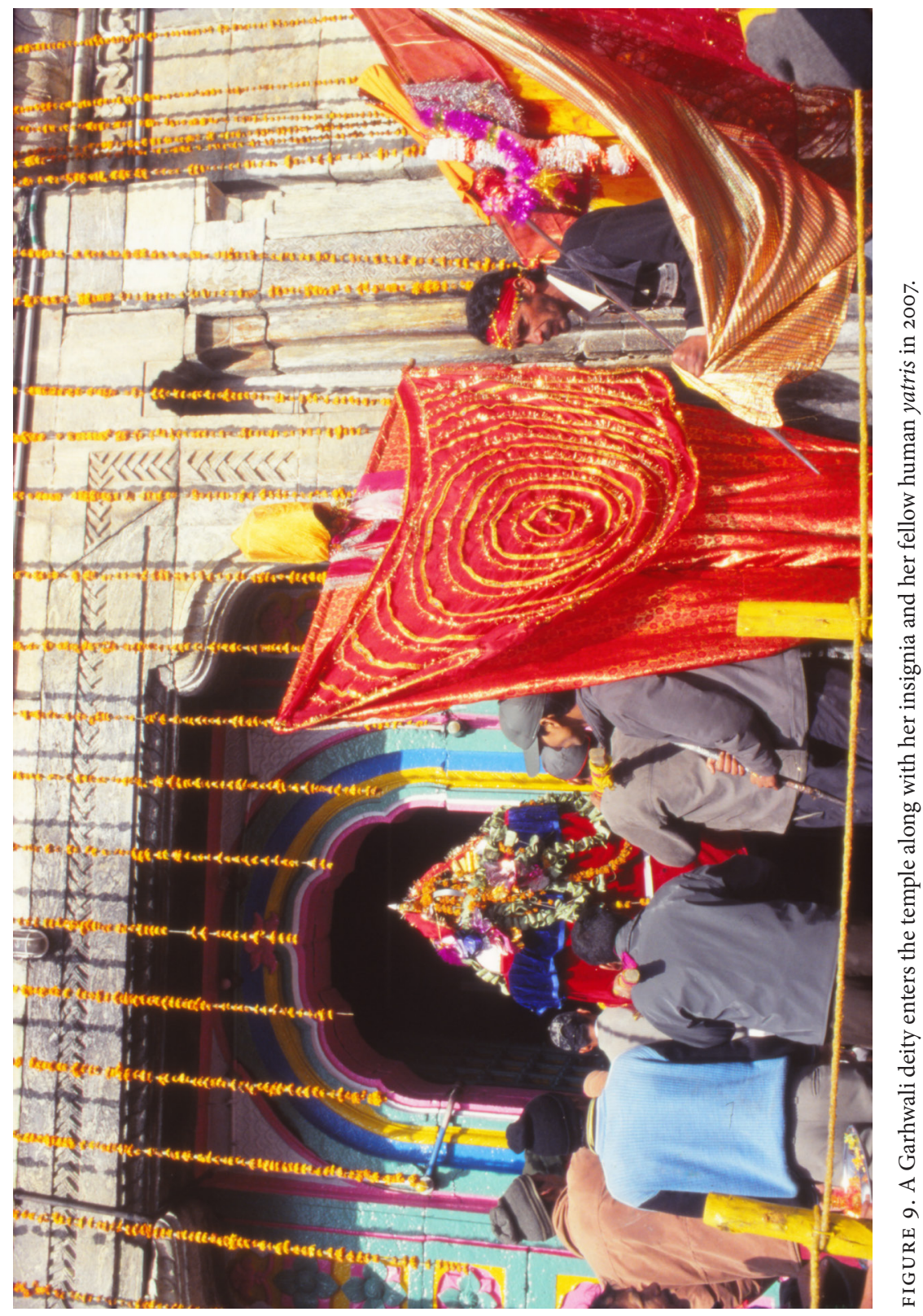


from the plains and gather for a variation of the Garhwali mela where they watch the deora yatris and the devta dancing/being caused to dance (Hindi: devta nacna, devta nacana). As when such possession happens in more typical village and town settings, everyone present becomes particularly focused and serious, extremely engaged with what is happening and what is becoming present. Yatris from the plains are frequently unable to interpret what is happening at such a time. Some assume that it is in fact Kedarnath-Shiva who has come into the courtyard. Others do not register immediately that it is a devta. Still others recognize it is as a devta, take darshan, and pay respect without necessarily understanding how exactly this particular devta has come to be where it is. A minority of yatris will ask a local to explain to them what is going on.

That evening I went to the dharamshala where many of the Nala Devi yatris were being hosted. Such an arrangement is, incidentally, a demanding situation for the tirth purohit. Traditionally speaking, the role of the tirth purohit in Kedarnath involves, in addition to carrying out all the ritual needs of his patron (Hindi: yajman), finding the patron lodgings and arranging meals. He is a host. However, unlike a lodge owner (there are in Kedarnath both dharamshalas and lodges), who may discuss the charges for services rendered up front, the tirth purohit cannot. He provides hospitality and performs puja and then cannot insist on the amount of the fee he will receive. Thus part of being a tirth purohit in Kedarnath is arranging expensive services (food for an entire village, for example) without necessarily knowing what one will receive in return. The situation invokes both traditional values of hospitality and selfless service (Hindi: seva) and the same time is shot through with uncertainty and anxiety because the patrons will not necessarily reciprocate with payment in the appropriate manner when the time comes. When a tirth purohit's Garhwali patrons come, however, I have noticed that they are usually much less worried about payment and view their hospitality actions more through the lens of Garhwali intervillage relations. It is customary for Garhwali villages to welcome deora groups with food and lodging as they journey on processions and yatras and to expect such hospitality when they themselves are on deora.

At one of the dharamashalas where the Nala group was being lodged, Bhupendra and I spoke with an elderly man from Nala and one of the older Kedarnath tirth purohits in whose dharamshala's canteen we were seated. According to them this was the third time that Nala Devi had come to Kedarnath. The first time had been at least four decades before, and Nala Devi had come not in a doli but in a basket carried on someone's back. ${ }^{5}$ The Nala man explained that Nala Devi came in order to obtain shakti. He went on to link her reasons for coming to his own, saying that there was certainly shakti in Kedarnath and that if there was not, then how would he, such an elderly man, have had the power to come to Kedarnath as he did?

Garhwali deities go on yatra for various interrelated reasons. One common explanation I heard many times was that Garhwali deities came to Kedarnath to 
recharge (Hindi: recharge karne ke liye): that is, Kedarnath is a charging station for smaller local deities whose "charge" periodically runs out. This was the case with Nala Devi. Another reason, usually much less discussed for obvious reasons, is for the expiation (Hindi: dosh nivaran) of a collective problem with supernatural aspects in a particular village or set of villages that the deity has often itself recommended through its oracles. A third reason is simply that the deity wished to go on deora and announced its desire by possessing its chosen representative, who then delivered the message, or that particular members of a village or the entire village wanted to go on yatra and to take the devta with them on the journey (Berreman $1972,103)$. Other possible reasons include the habits of a particular deity to go on deora once every set number of years or its desire (not limited to going on deora) to exercise sociopolitical authority in its community (Jassal 2016). During my time at Kedarnath there were deoras of Garhwali deities who came every year, deities who were coming for the first time in forty-five years, and deities who had never previously made the trip. When deities came to Kedarnath, they were worshipped as deities by their devotees but also, relative to Kedarnath-Shiva, they behaved in many respects like a paradigmatic human devotee. A designated human representative (Hindi: pratiniddhi or in the Garhwali of the Kedarnath valley: naur), often the person whom the deity regularly possessed if a specific person existed, acted on behalf of the deity.

Early the next morning, the deora yatris went to the temple and, having done parikrama, entered it; to the sound of drums they then brought Nala Devi out into the courtyard. Bhukund Bhairavnath possessed his naur as well, a Kedarnath tirth purohit from the village of Rudrapur in the Kedar valley. This appearance, while brief, meant that Nala Devi was being welcomed and invited to make herself at home by the guardian of the valley.

After receiving the permission of Bhukund Bhairavnath, Nala Devi began to engage the place beyond the temple and the village. Her itinerary for the day in many ways constituted a map of people, locations, and practices outside the temple that were significant to Kedarnath in 2007. From the courtyard Nala Devi headed out of Kedarnath to the north to bathe in the Saraswati River (which I sometimes heard referred to as the Swargdhari or Swargdvari), a smaller river flowing in from the northeast that joins the Mandakini River about a kilometer behind the Kedarnath village. The government had created a massive barrier wall that began just behind the northwestern edge of Kedarnath village and ran diagonally northeast behind Kedarnath so that the river would not overrun its banks and flood the village. This boundary wall washed out in 2013, and one of the major reconstruction projects was the rechanneling of the Saraswati River back to her pre-2013 course. Nala Devi's bath in the Saraswati (recalling that there was a bathing ghat on the banks of the Mandakini River at the entry to Kedarnath village in which she had already bathed) can be read as an acknowledgment of the numerous sites of power (many of them rivers) lying just north of Kedarnath 
village that are described in the Kedarakhanda, discussed in chapter 2. On the way to bathe, however, Nala Devi stopped briefly at the free food kitchen (Hindi: langar) of the renunciant Mahant Chandragiri.

Nala Devi stopped briefly and bowed at the recently built hall of Adi Shankaracarya before continuing to the Saraswati River. Upon arrival at the banks of Saraswati, Nala Devi dipped her canopy/umbrella (Hindi: chatr) in the water. Her doli was then seated on the banks, and all of the scarves and insignia were taken off, put down, and immersed separately in the river, a procedure that took about an hour. The bathing concluded with a small puja. Ganga (Saraswati) water was sprinkled over Nala Devi, and the dhol and damaun drum players also sprinkled Ganga water over their instruments. With cries of "Jay Ganga, Jay Lalita Maya, Jai Kedarnath," the doli was picked up again and, after some discussion of whether to go first to Bhukund Bhairavnath, Nala Devi returned to Kedarnath. She returned by a different path, entering Kedarnath from the northeast, and went to the Samiti compound, stopping by the small shrine where the food offered in the temple was prepared (Hindi: bhog mandir). The Ved-pathis all came out and prostrated in front of her, and she bowed to them. People then asked for the Samiti officer in charge of the rations, supplies, and preparation of the offerings for the temple (Hindi: bhandari). The bhandari officer came, and Nala Devi thanked him for providing supplies for her and her deora yatris; the group was the guest of the temple committee while in Kedarnath. Yatris would sometimes come to this area to have an audience with the Virashaiva pujari. Otherwise, this was a primarily a local area.

Nala Devi then reentered the temple for puja. Other yatris who were in the temple at that time were hastened out as quickly as possible. The doli was put down opposite the linga, and important local purohits and the important members of the deora yatri group sat on either side. The tirth purohits carried out the puja on behalf of Nala Devi. This puja, unlike most of the pujas done in the Kedarnath temple, was basically a collective puja that stood in for individual family pujas done by members of the deora yatri group. Thus each family present was instructed to say its name and zodiac sign (Hindi: rashi) near the beginning of the puja so that they would be included in it. Those wearing a sacred thread took it off to make their vow of ritual obligation (Hindi: sankalp) and then put it back on. Nala Devi's insignia were also placed on the linga during the puja, presumably also for recharging. ${ }^{6}$ The inner sanctum was by this time empty of any other yatris, though one tirth purohit was quietly reciting Vedic mantras in the corner.

Several verses were recited from the Seven Hundred Verses to Durga (Sanskrit: Durga Saptashati), and the puja proceeded through a fairly normal sequence: Ganesh puja, praising of Ganesh, and concentration (Hindi: dhyan) on Brahma, Vishnu, Mahesh, Shankar (Shiva), and Kedareshvar (Shiva-in/as-Kedarnath) in turn, along with relevant verses. The tirth purohit poured water onto the linga, on behalf of Nala Devi, and offered whole rice, applied what on a human devotee 
would be a forehead mark (Hindi: tilak) derived from auspicious substances offered during the puja such as sindhur powder or sandalwood paste, offered a sacred thread, recited verses in praise of Shiva from texts such as the Hymn of the Greatness of Shiva (Sanskrit: Shivamahimnastotra), and performed arati. $^{7}$ The deora yatris were told collectively at various points during the puja to bow their head to the linga. After the arati the tirth purohit massaged the linga with ghee on behalf of Nala Devi. Everyone, deora yatris and Nala Devi alike, circumambulated the linga before leaving the inner sanctum, stopping on the way out to worship Parvati. Upon emergence from the temple, Nala Devi then circumambulated the temple from the outside and headed up the side of the valley for Bhairavnath puja. At this point activity bifurcated. A group of ten to twelve purohits remained by the Havan Kund, a covered raised platform on the eastern side of the temple that was both the standard location for large fire offering rituals (Hindi: yagya or havan) in Kedarnath and the base of operation in the temple courtyard for renunciants. They began a yagya sponsored by tirth purohits from Rudrapur (the Kedar valley village that is the natal village of Bhukund Bhairav's naur). Nala Devi went up to the shrine of Bhukund Bhairavnath, and a brief puja was performed to Bhukund Bhairavnath. Many yatris make the small trek (approximately fifteen to twenty minutes in each direction) to the shrine of Bhukund Bhairavnath if they have the time and energy to spare. Fewer yatris, except for the nature-oriented trekkers who both have the inclination and have planned to include time for a longer stay, proceed to wander about on the high plateau immediately behind the Bhairavnath shrine. Here Nala Devi began again to display a marked desire to move about the broader area of the Kedarnath end-valley.

Nala Devi's actions here illustrate the ways in which significant practices (of both deities and humans) in Kedarnath do not limit themselves to focused interactions with specific sites. From the shrine of Bhukund Bhairavnath, Nala Devi began to wander (Hindi: ghumna). This wandering distinguished the three local Kedar valley devis who come to Kedarnath from the other Garhwali devtas who visit. Nala Devi, Phegu Devi, and Rampur Devi all are known to potentially wander over much of the length and breadth of the Kedarnath end-valley. Ghumna, or ghumgam, is the Hindi word used by locals when they describe a jaunt by foot they have taken that was not for a specific purpose other than to enjoy a walk; in this sense Nala Devi was acting like a Kedarnath valley local in Kedarnath, which she was. She first headed south on the Bhairavnath plateau halfway down the eastern side of the valley to a large rock known by some as "Old Kedar."

From "Old Kedar" Nala Devi came down the hill near the helipad. By this point a cold rain had begun to fall. As Nala Devi started to turn north, the deora yatris began trying to convince Nala Devi to stop wandering and head back to the bazaar. Bhupendra and I remembered their conversation as something like the following: "Speak, what should be done, if you need to keep wandering then say so, but in this rain we cannot help you wander any more. Also now it is necessary to 
go into the bazaar, everyone has invited you. We would like to take you to at least half the places in the bazaar today-the rest is up to you [Hindi: baki teri marzi]." This conversation serves as an important reminder of the challenging conditions one finds at Kedarnath. At 3,500 meters of altitude, walking wet and barefoot around the end valley in a cold rain with the temperature only a few degrees above freezing was difficult enough that the deora yatris, themselves mountain dwellers (Hindi: pahari) were willing to challenge their deity. Given that the satisfaction and beneficence of the deity is a large part of why villages bring their deities to Kedarnath, this is a telling indicator of the physical state of the deora yatris at this point.

Nala Devi began to head back to the bazaar. On the way, she stopped at Retas Kund, a pool of bubbling water enclosed by a shrine that (as mentioned in chapter 2) for tantric practitioners possesses important alchemical significance, and as hundreds of thousands of other yatris have done, once a sound was made (in this case a conch was blown) the group saw bubbles come up through the water in the pool. She continued on through the center of Kedarnath and returned to the hall of Adi Shankaracharya (i.e., Shankara) on the eastern side of the village in response to the invitation of an important renunciant from Varanasi who bore the title Mahamandaleshwar. The Mahamandaleshwar was carrying out a twomonth period of extended devotion, meditation, and puja (Hindi: anusthan) in Kedarnath as part of his program to carry out a series of anusthans in each of the twelve jyotirlingas. The hall of Shankaracarya was a recent structure that housed the ostensibly original location (Hindi: sthal) of Shankara's passage into liberation/ death (Hindi: samadhi) along with a murti of Adi Shankaracarya as well as a new, gigantic linga made of crystal.

For most of August and September, the hall of Adi Shankaracarya was the site for the public daily puja and atirudra yajna (an especially elaborate form of the Rudri/Rudrashtadhyayi fire offering ritual that lasted for the entirety of the two months of the anushtan) of the Mahamandaleshwar. The Mahamandeleshwar had hundreds of followers visit him during his two months in Kedarnath, especially in the last week, culminating in a celebration of the final offering of the yajna (Hindi/Sanskrit: purnahuti or "last offering") in which all present made the final offering into the fire together, a celebration that involved conservatively several hundred people. He ventured only rarely to the temple. It was clear in discussion with many of his followers that his presence was the primary motivating factor for their journey.

The Mahamandaleshwar and the Brahmins he employed for his yagya (composed of both local tirth purohits and Garhwali Brahmins from other parts of Garhwal) worshipped Nala Devi with verses from the Durgasapashati and $s v$ asthi vacana mantras. Then all the deora yatris were given chai and snacks. Nala Devi then left the hall of Shankaracarya and went to the bazaar. In the bazaar, 
Nala Devi stopped at almost each shop, where she was garlanded with flowers and scarves, was sometimes worshipped with a small puja, was given small gifts of money and rations, and then was asked for blessing (Hindi: ashirvad). Several older local women who were visiting Kedarnath for several weeks (wives, aunts, and grandmothers of Kedarnath tirth purohits) garlanded her. At this point in her visit her activity was no longer that of a yatri in Kedarnath. In the bazaar she was a Garhwali deity on deora in a bazaar filled with people from her own area, people to each of whom she owed darshan and ashirvad and who were bound by the especially high level of reciprocal obligations of offering implied by her status as a local devi of the Kedarnath valley.

At this point the deora yatris again requested/told Nala Devi to go straight back to her resting place, saying, "We cannot help you to wander any more in this rain." She then returned to the dharamshala where she was based and remained there at rest until eight in the evening, when she received arati. While she was resting, at about 5:30 p.m., Rampur Devi (the second local devi of the season) arrived and was greeted in much the same fashion. The next morning, Nala Devi and her deora yatris got ready for departure. Some of the yatris were having their family details recorded in the book of records (Hindi: bahi) that tirth purohits keep of the visits of their patrons. Nala Devi went and circumambulated the temple before visiting more shops and several lodges on her way out of Kedarnath.

The visit of Nala Devi to Kedarnath marked one of the moments when Kedarnath became a Garhwali place, a place where Garhwali attitudes surrounding the presence of devtas on the move superseded the economic aspects of yatra and temporarily reconfigured many other normally operative distinctions between locals and yatris who were usually from outside the region. ${ }^{9}$ Her visit, the visit of a paradigmatic yatri, showed that while the temple was the primary focus of her visit she also made it a point to pay her respects to Bhairavnath, to bathe in the river in two different places, and to wander across the land in the midst of challenging weather. She engaged the place as a whole in a way that muddies distinctions between nature and deity, local and visitor, temple and place, human and divine agency.

\section{THE GHEE MASSAGE}

The massaging of the linga with clarified butter or ghee (Hindi: ghee malish), on the other hand, enacted a spatial focus that was closely focused on Shiva's presence in the inner sanctum of the temple itself rather than the spatial focus of Nala Devi that was spread out over the entire end-valley..$^{10}$ In the Kedarnath of recent decades anyone could, as part of puja, touch the linga in the inner sanctum of the temple during the time for public puja in the morning and massage it with ghee with her or his own hands. Anecdotally, this practice appears to have replaced the practice 


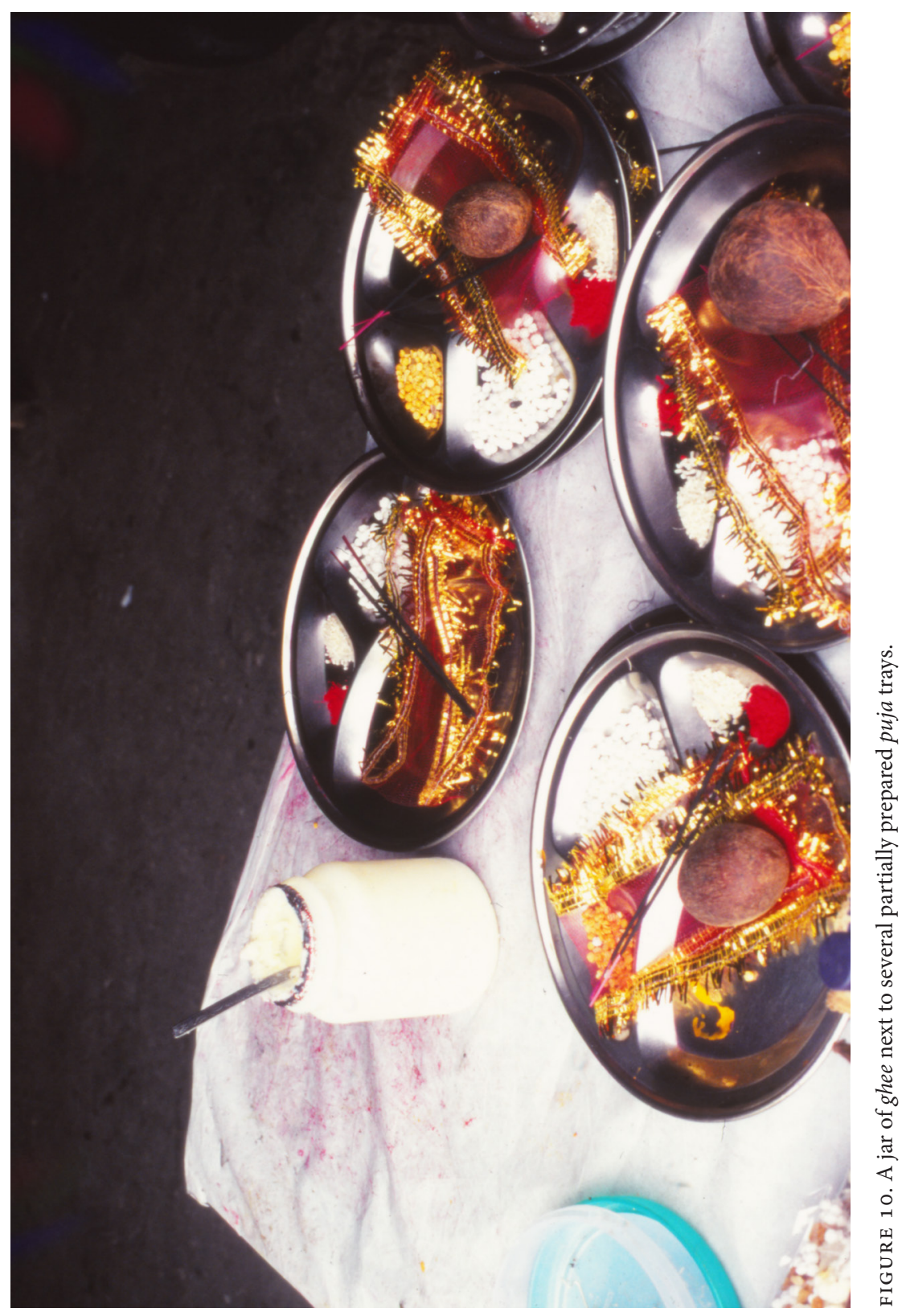


of embracing the linga that some older tirth purohits remember from earlier decades and that had been mentioned by earlier visitors to Kedarnath, a practice that would have been easier before the linga was enclosed in the metal frame, the state of affairs in 2007. Many Kedarnath locals loudly insisted that Kedarnath was the only place where this ghee malish was performed. Many yatris informed me that this was not the case, but it is nonetheless the most distinctive practice currently linked to Kedarnath and does stand as a unique practice for many. ${ }^{11}$

At the beginning of the 2008 season, it was still the tradition at Kedarnath that every single person or family could have a seated puja in the inner sanctum itself. This full access was often contrasted with the highly limited access to the deity yatris typically experience in Badrinath. The puja itself was fairly standard and often included an abhishek of the linga (Hindi: the bathing of a murti with auspicious materials). Standard puja offerings usually included a sacred thread, camphor, incense, whole dried rice, oil lamps, forehead adornments (Hindi: bindi), vermillion powder, nuts, split chickpeas, and raisins, and more expensive pujas added scarves, plastic flower garlands, and coconuts. Sometimes yatris would bring some of the materials for the puja from home. Even the least expensive puja tray always came with ghee. Puja took place in the inner sanctum of the temple around the periphery of the metal frame enclosing the linga. This was the general ritual sequence: invocation (Hindi: avahan), initial vow (Hindi: sankalp), puja, arati, and offering of flowers (Hindi: pushpanjali), and then ghee malish. Each member of the family would take semisolid (because of the air temperature) ghee into their hands and was urged to rub/massage the linga with ghee while the purohit recited a mantra:

I am a wicked person [Sanskrit: papa], I am one whose actions generate wickedness, my inner being [Sanskrit: atma] is full of wickedness, I am one from whom wickedness arises. Save me, lord of Parvati! O Shiva, you destroy all papa. ${ }^{12}$

The meaning of the mantra accords with the sense that the end of the puja sequence, in the Kedarnath valley, often includes a declaration of the sponsor's unworthiness and a blanket request for forgiveness from the deity. ${ }^{13}$

For many yatris this intimate embodied encounter with the linga is extremely special, an experience usually unavailable to them. For others it is merely an elaboration of something they already know. There was often the sense that the ghee malish derived in some way or other from the paradigmatic actions of the Pandavas. Returning to another part of the discussion with the tirth purohit Tiwari-Ji discussed at length in chapter 1 provides an example in which the ghee malish was connected specifically to Bhima. When I prompted Tiwari-Ji about the ghee malish during our conversation, he responded:

They say that Bhima hit with a mace at that time, saying, "Where has he gone, all of them have gone." He did not have intelligence, he had strength but not intelligence, it is well known ... that, regarding someone who has strength ... he is totally mindless 
["mindless" said in English]. That's how it happens. ... He had very little thinking power. ... He hit God and then pulled him.... Therefore, Mother Kunti said, "Son, you made a great mistake." When God [Hindi: Bhagwan] gave darshan there and when he became invisible again, Mother Kunti said to Bhima, "You should apply a repair ... to where you hit God with a mace," and there that repair is applied. "I am a wicked person, I am one whose actions generate wickedness, my inner being is full of wickedness, I am one from whom wickedness arises. Save me, lord of Parvati! O Shiva, you destroy all papa" [mantra recited in Sanskrit]. Doing this, the repair is applied. ... For the expiation of wickedness, ghee is applied to God.

In the context of a book describing the relationship of the Virashaiva tradition to Kedarnath commissioned by Kedarnath Rawal and Virashaiva jagatguru Bheemashankar Ling, Shobha Hiremath (2006) writes of the ghee malish in this way: "The most mysterious and astonishing point is when you caress the linga form of the Jyothirlinga [sic], you can feel the backbone and nerves of the back of the male buffalo, each and everyone irrespective of caste colour and creed is permitted to touch, feel, and express their devotion by smearing butter to the linga as a religious ritual. The souls of the devotees soar high with reverence and ecstasy." Whatever the valence, a ritual personal encounter with the distinctively shaped linga, thickened by connections to webs of experience and meaning about Shiva and his paradoxical formed formlessness, his connection to the Himalaya and to the Goddess, and his interactions with Pandavas, has been a central part of visiting or residing in Kedarnath for many.

The ghee malish, carefully analyzed, can be seen as a model that maps to broader trends, experiences, and textures found throughout Kedarnath. Specifically, it can serve as an analytic microcosm for understanding the stresses of the high season. To understand how, it is first necessary to briefly review the temple timings. In 2007 and 2008 a normal day in the Kedarnath temple began with the Kedarnath pujari offering food (Hindi: bhog) to Kedarnath-Shiva at around 4:15 a.m. After this came the time for special puja (Hindi: vishesh puja), puja typically involving the presentation of costlier offerings in greater quantity, for which a ticket had to be purchased from the Samiti. Any puja performed during this time required the presence of a Brahmin ved-pathi who was a Samiti employee, even if the patrons of the puja wished to use their own tirth purohit as well. General darshan and puja were available from 6:00 a.m. until 3:00 p.m. This time was often described as the time of bliss-darshan (Hindi: nirvan darshan). ${ }^{14}$ At this time anyone who waited in the queue could directly touch the linga and sponsor a puja in which each devotee could massage the linga with clarified butter (Hindi: ghee) with his or her own hands. This opportunity is not always available in large temples and was often mentioned as a special aspect of visiting Kedarnath.

At three the temple would close and the inner sanctum would be cleaned, followed by the daily fire offering (Hindi: havan) and the offering of the second 
bhog of the day, and the pujari and his assistant would begin the adornment (Hindi: shringar) of the linga that preceded the evening temple puja. After the second bhog, only the pujari and his assistants could enter the inner sanctum. The doors opened at 5:00 p.m. for what was often called adornment-darshan (Hindi: shringar darshan), and then evening puja and the offering of light and flame (Hindi: arati) typically commenced at 6:00 p.m. and lasted approximately one to two hours. During this time yatris passed briefly in front of the door to the hall between the antechamber/public hall (Hindi: sabha mandap) and the inner sanctum for a brief shringar darshan from afar. Around 8:00 p.m. the temple would close until the next morning. Diana Eck (2012, 231) evocatively characterizes the relationship between the nirvan darshan of the morning and the shringar and arati darshan of the evening: "The rhythm and juxtaposition of these two evoke in ritual the Shaiva theology of a god who is both describable and indescribable, both apprehensible and utterly transcendent."

Evening arati in Kedarnath was a special time. After a luminous glimpse of the adorned linga, a brief moment obtained amid a press of excited devotees, you exited the temple and circled it in the auspicious direction as evening fell. You then joined the growing crowd of people in the temple courtyard who had already taken darshan, a crowd that included yatris and many locals who were taking a short break from their duties. People were singing devotional songs (Hindi: bhajan) from home. Some lit lamps and placed them on the ground or one of the temple walls or made a donation to one of the sadhus whose "duty" it was to stand outside the temple during evening arati. More so than during the day, the crowd in the temple courtyard included many of the police stationed in Kedarnath, a reminder that Kedarnath is close to the border of the Tibetan Autonomous region and that the state and national governments pay careful attention to what happens here. At the end of the arati the Virashaiva pujari, accompanied by his Garhwali Brahmin assistant, both of whom are today employees of the Samiti, strode outside and offered the light-flame of the torches of arati into the darkness first in the direction of Bhukund Bhairavnath and then to the assembled crowd. Evening arati was usually a time when one felt a bond with others because everyone was in this special place at this special time. It was a moment that illustrated the idea, discussed in the Introduction, that the shakti of Kedarnath is either/both inherent in the place and a result of the accumulation of what people have brought with them to Kedarnath over the centuries.

In the high season in 2007 and 2008 these timings changed dramatically. Special pujas began as early as 11:00 p.m., preceded by the (technically the next day's) morning bhog, and continued until around 6:00 a.m., when the doors would open for general darshan and puja. Yatris waiting for general darshan and puja often had to wait for two to five hours. In 2007, I never saw the temple close for the afternoon until all yatris had been through the temple. This policy effectively 
pushed back the rest of the day's schedule by several hours. In the third week of the 2008 season, I saw the doors close at least once (to the best of my knowledge for the first time) at 3:00 p.m. before everyone had received darshan. In 2007 and 2008, it was not clear that the ghee malish would continue in its current form because the ever-increasing numbers of yatris present in Kedarnath during the high season were making it difficult to provide every yatri with the opportunity for seated puja, and there was a great deal of speculation about how the ritual might need to change. These incipient changes in temple ritual illustrate the stresses placed on Kedarnath by the high season. ${ }^{15}$

\section{THE HIGH SEASON}

The high season was a time when the complex eco-social system of Kedarnath was bursting at the seams, a high-altitude whirl of religious power, devotion, sightseeing wonder, big business, power struggles, changing weather, and overcrowding. The differing ways that the connotative web of story and ritual described in chapter 1 and chapter 2, blended with the complex imaginations of landscape whose trajectory I described in chapter 3 , framed experiences in Kedarnath were on full display in the brief scenes and conversations I describe. There was also a high degree of variation (and overlap) in the spatial setting receiving focus at any given moment: sometimes the temple, sometimes the physical context of the path, sometimes the story-enchanted Himalayan landscape in a bigger sense, and sometimes the inner landscape of the speaker. Perspectives on Shiva's presence in the place and/or the temple could be seen to vary in these scenes as well.

The first several snapshots I present in this section are from May 13, 2007. This day began in a large dharamshala. My conversations usually took place in the entry room, unless the manager conducted us to one of the rooms and asked a group if we could speak to them in their room. I first spoke with a middle-aged woman from Mumbai who was doing the Char Dham Yatra for the first time. She had originally meant to come the day before, but there had been a strike by the horse-drivers against the growing number of helicopter flights, so they had come one day later, causing them to miss a 2:00 a.m. appointment for special puja. They had brought all of their own supplies with them for puja. They had not heard prior to arrival the story about how the Pandavas came to Kedarnath, but they did know that Shiva had become manifest (Hindi: prakat hue) in Kedarnath by his own volition. They had tried to walk from Gaurikund, but after three kilometers they began to have difficulty breathing, so they paid someone to carry them in a palanquin (Hindi: palkhi) the rest of the way.

I had already heard about this strike. The day before I had been sitting at one of the tents by the helipad provided by one of the private helicopter companies for 
the use of customers and employees. At that time, I had spoken with one of the helicopter company managers and a three-generation family of yatris from Andhra Pradesh. The father was an industrialist. He said that Kedarnath was a better place to go on vacation and waste money (Hindi: paise barbad karna) because not only was the scenery better than that of a hill station but also there was the added benefit of darshan. Yatri families will often mention that one purpose of a family yatra is that it may help to instill traditional values in the children of the family. He was indignant that the horse drivers and porters were striking against the increasing practice of journey to Kedarnath by helicopter. Didn't they understand that more jobs would be created by the economic development resulting from these helicopter yatras? The helicopter company manager, a Kedarnath valley man, said that the horse-drivers had become stubborn like their animals and were protesting because they were not receiving any compensation from the helicopter companies. When I pointed out that some people felt that Kedarnath, as a traditional place of pilgrimage, was meant to be difficult to reach, he became testy. Are you trying to tell me, he asked, that my old mother should not have come? She could come only by helicopter.

Later that day, out in the bazaar, I was invited to tea by a policeman whose duty was to keep order in the temple line. He insisted that only 1 to 2 percent of the people who came to Kedarnath were true devotees (Hindi: bhakt). The rest had come only to make a perfunctory touch of the linga. They were not even willing to endure the pain (Hindi: kasht) of waiting in line for a little while or coming on foot. He was also extremely critical of people who could afford to come by helicopter and purchase a ticket that granted them the permission to enter through the side door without waiting in line. He felt that kasht was a requirement for bhakti. This reminded me of something a Hindi teacher of mine once said about her experience of puja. Often during puja, she said, people put their kasht onto God (Hindi: Bhagwan). But what about the kasht of God? When she did puja she tried to take on God's kasht.

Arrival by foot in recent years has carried particular resonances. Pilgrimage by foot (Hindi: paidal-yatra) is the iconic form of yatra and symbolizes the pain (Hindi: kasht) and inner production of energy and focus (Sanskrit: tapas; Hindi: tap) that the practice of yatra generates (Whitmore 2016). Yet in 2007 and 2008 (and later when I visited in 2011), to walk to Kedarnath was to be in a dwindling minority. Far more common was to ride on horseback, to be carried by porters, or to come by helicopter. Helicopters passed overhead several times an hour. If you arrived by helicopter (which I have never done), then you overflew the path, armored by your ability to purchase the ticket but also temporarily cast as an observer of the older, more traditional forms of pilgrimage taking place beneath you. You experienced a wide view of the mountains and the river valley. If you were in a helicopter flying up the Kedarnath valley, then you were flying at almost 


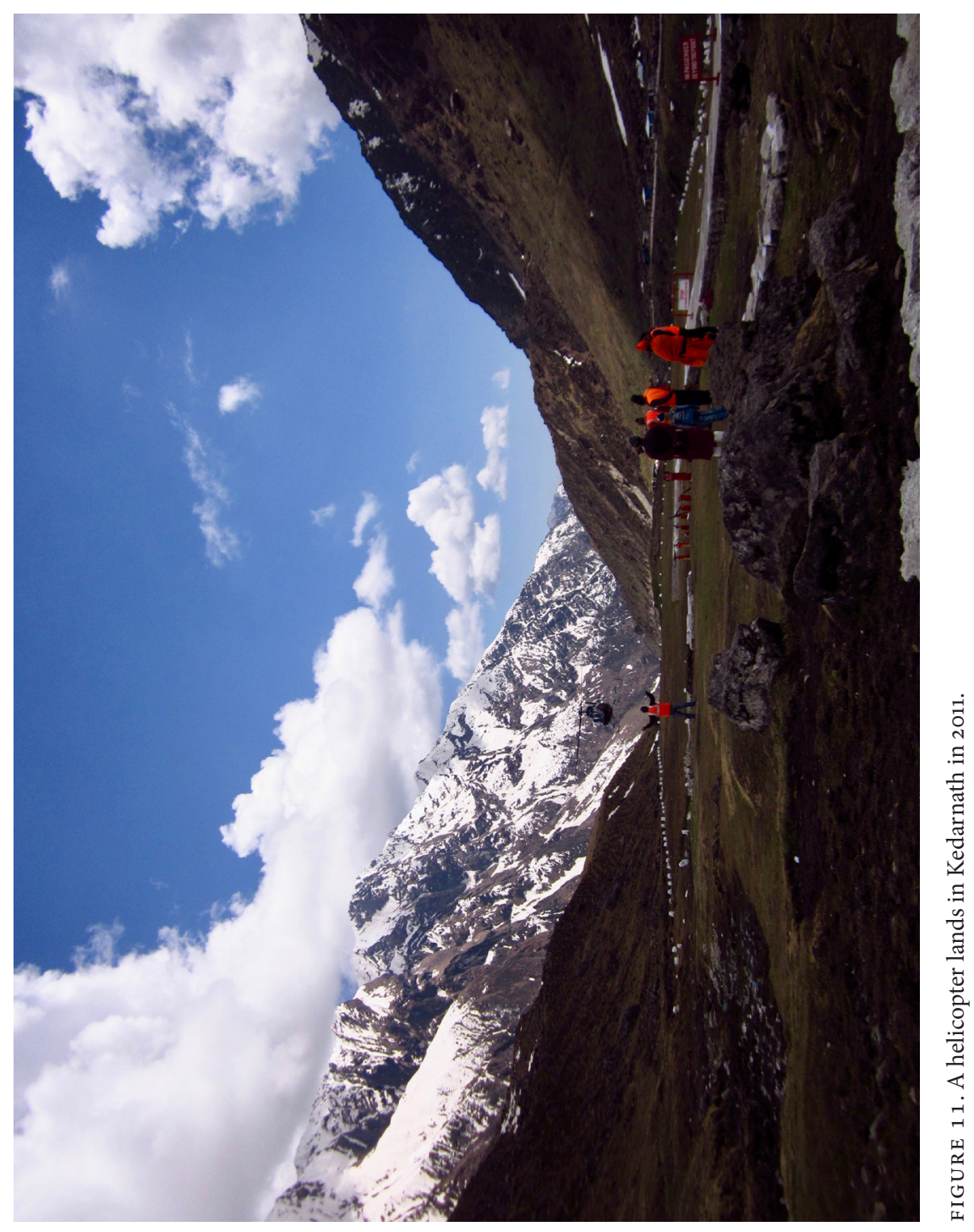


half of the height at which commercial airliners fly at cruising altitude. But, of course, this was somewhat removed from the practice of walking in the footsteps of the Pandavas.

In early afternoon I headed toward the temple courtyard. The queue was long and the police were required to intervene to keep order as quarrels broke out between those patiently waiting in line and those attempting to jump the queue. I did not wait in line but wandered up and down the line and tried to talk to people, with moderate success. Then the weather turned. In nonmonsoon Kedarnath it was common to have strong sunlight and clear weather in the morning and early afternoon, but clouds and precipitation would often arrive in the mid- to late afternoon. You could usually see the cloud wall advance up the valley with measurable speed in the afternoon. I went and sat in a shop owned by a friend of mine that sold religious objects and books. A group of yatris from Gujarat were castigating him for not having more material written in Gujarati. Several women wanted to buy cassettes of devotional songs (Hindi: bhajan). He responded curtly that he no longer stocked cassettes and that they should purchase a Char Dham video instead. ${ }^{16}$

I went again to a large dharamshala, this time for a prearranged conversation with a teacher from Delhi on his nineteenth visit to Kedarnath. I was able to partially record the conversation, which took place primarily in English with frequent excursions into Hindi. He said that he had been to all of the jyotirlingas at least sixteen times and that he had sponsored and carried out twelve maharudrams, a maharudra being over one thousand recitations of the Sri Rudram Vedic chant (Sanskrit: Rudrashthadhyayi). He mentioned a pilgrimage system known as the seven Kailasa that included Manimahesh in Himachal Pradesh and Kedarnath. He contrasted India as a place of mystery with America, where people are interested in demystifying. He said that in India science and tradition are integrated and gave the example that anointing the forehead with sandalwood paste (Hindi: chandan tilak), commonly done after some forms of puja, releases endorphins that give you pleasure. When I asked him about the shape of the linga he said that it was the shape of the Himalaya. He told a version of the Pandava story in which he said that Shiva initially had been aloof from the Pandavas because it was not yet the proper time for their darshan. When Shiva took the form of a buffalo Bhima perceived it and stood his legs on two hillocks. Shiva, as Lord, could not walk between Bhima's legs. At this point Shiva realized that Bhima had understood his disguise, so he went into the earth. The hump of Shiva remained in Kedarnath and the Pandavas went to heaven. His navel became established in Madmaheshwar, his matted hair in Rudranath. Ravana, the archvillain of the Ramayana, had actually visited Chopta, the tourist town on Ukhimath-Joshimath road that lies just below Tungnath, another of the Five Kedar shrines. The teacher also mentioned "Old Kedar" (Hindi: Budha Kedar), a Shiva temple near Uttarkashi connected 
to the Nath tradition but not often connected to the Five Kedar shrines. He also mentioned Pashupatinath in Nepal and said that darshan of Pashupatinath was necessary for getting the benefits, or fruit (Hindi: phal) of the journey to the different jyotirlingas.

When I asked him about the ghee malish, he said that the reason for it was practical. It was difficult to grow flowers near Kedarnath, whereas it was easy to offer ghee. I asked him why he kept coming to Kedarnath. He said that every time it was different and unique. For example, this time was the first time the weather was clear. Once he came in October and there was a heavy snowfall. They had no clothing. He used to come half-naked (recently he has started bringing gear). Once he came when it was raining and everything got soaked. Once he came in October with nothing. Today's worship had a different vision, a different feeling. He started to talk about a renunciant who had been staying (reputedly continuously) for twenty-seven years in the Ramanandi ashram built into the mountainside at Garud Chatti several kilometers south of Kedarnath on the path. He said that this renunciant had kept very quiet until the last two or three years and had finally begun to share. Sharing experiences was good. Always something was different. This teacher always journeyed to Kedarnath on foot, even though he used to have varicose problems. Now he had diastolic dysfunction (a swollen heart) and it took him twelve to fourteen hours to walk up, but still he came.

When I asked him about experiences in the inner sanctum he had this to say:

Sometimes you get . . . feelings. Sometimes you get visions, sometimes you see something. [I asked for an example] ... I don't know, I don't remember, but it is there. Some visions come, some noise comes sometimes. Some days we are with ourselves only, we just keep on chanting. ... Sometimes you feel smells ... sometimes you feel some ... vibrations ... after that one should not say all these things because one does not know what it is exactly. Generally, they are saying you should not share such things but since you are asking...

He himself sometimes got a sort of ticklish feeling, sometimes felt as if he were naked and would cry. There was a beginning, a straining toward a beginning. He said that one of the problems with sharing experiences was that there were dangers. Development on a spiritual path could be very dangerous, as could sharing. Each stage felt like the ultimate. I asked him if he felt that Shiva possessed name, form, and attributes that could be expressed through language (Hindi: sakar, also termed sagun). He said Shiva ultimately was both formed and formless. If you worshipped Shiva as sakar then you saw a material form. The experience was no doubt sakar, but it was so powerful that you could not bear the full sakar form. For example, the full form of Lord Ganesha was as powerful as millions of suns. We could not bear even one form. Thus we used idols (his term) and lingas. The problem was that people got stuck. You had to go ahead and keep progressing as if you were progressing through a system of education. There was no difference between Islam 
and Hinduism except that one started with the formless (Hindi: nirakar, the opposite of sakar). You had to be very powerful to perceive the nirakar. You had to start with form because formlessness was too hard.

He related what he told his students because he often brought students with him on his pilgrimages. He used particular events and experiences as justifications for worship of Shiva. It was because of the protection of prayer, for example, that a train journey had been successful in a time of terrorism. Last year on a trip to Madmaheshwar they had left Rhansi at five in the afternoon. He had injured his legs and the group had gotten lost. Twenty-one students were on one the wrong side of the river valley. People were crying. Suddenly someone appeared and guided them. If it was not a miracle, then it was an amazing coincidence. Another time he was traveling to Kedarnath and he had an oxygen problem in the fog. Someone came and guided them up to the bridge and then vanished. He explained that by "vanished" it meant that the mysterious person suddenly went away quickly and they searched and could not find anyone. Students also had mentioned an approximately eighty-year-old man who helped them once and then disappeared too quickly for someone of his age. Sometimes local people said that they heard voices at night sometimes, for example in Garud Chatti. The teacher mentioned the oft-related story about Badrinath that in places like Badrinath and Kedarnath for six months the gods came and worshipped here. He once had seen a man on the path who was moving but without walking. He thought it must have been the deity Kal Bhairav (Bhairavnath) or some semidivine and/or monstrous member of a troop (Hindi: gana) of Shiva's followers or some ancient saint. He mentioned several similar occurrences in and around Badrinath that involved sightings of Uddhava, a friend of the god Krishna.

We began to discuss the ways that Kedarnath had recently been changing. The teacher said that the essence of Kedarnath would not change because of recent development but that there would be so many layers over that essence that people would not be able to see the true character of the place. He likened this problem to the ways that the seven sheaths (Sanskrit: kosha) of bodily material prevented us from directly perceiving the life force (Sanskrit: prana). Walking to Kedarnath barefoot was better for getting the full experience of the place, an experience that involved both pain and pleasure, but of course not everyone was able to do this. It would be good if the nearby glacial lakes of Gandhi Sarovar and Vasuki Tal became more accessible, but this might spoil their atmosphere. People were beginning to be trapped by a strict yatra schedule, which meant that they were more likely to just go to Badrinath or to rush through the Uttarakhand Char Dham Yatra.

At the same time, even in Mumbai intense bhakti was happening for lots of people. Coming here was not strictly necessary, but for certain kinds of religious experience one had to wander like the saints. There must be a purification process, the banana must be unpeeled. He said that I should be like the chiku seed and not like the mango seed. The chiku seed was totally dry and could be cast aside, whereas 
the mango seed always seemed to have a bit more juice and therefore could not be cast aside. Being in the world was good. He told students: get involved but not attached. You have to taste the world. As the conversation ended, he said he hoped that he had not wasted my time. When people like me came, unfortunately most people like him were not able to explain adequately. Most of his students did not learn through his explanations; instead he had to create the conditions for them to have learning experiences of certain kinds because he was interested in their salvation. He gave the example that he had once caused his students to perform an abhishek with seven liters of milk. They had found this wasteful at the time and later they understood. Most of his students were elites who liked Western things and did not believe in traditions but rather thought of them as myths, so their minds had to be changed slowly. At the end of the conversation he gave me a laminated AUM/OM image for my own use.

Finally, Bhupendra and I visited a different large dharamshala. There a Kedarnath valley local friend who worked for a national yatra company introduced us to a group of about twenty-five yatris from Gujarat as they were eating their dinner (provided by the yatra company) in the canteen of the dharamshala. It was clear that they were having a blast. I stood in front of them and introduced myself and a rowdy question-and-answer session followed. Members of the group felt that the pursuit of the Pandavas was appropriate because they were in pursuit of mukti. They said that Kedarnath was Shiva's dwelling place (Hindi: nivas) but that Shiva was not Kedarnath. Many people were hearing the story of the Pandavas' journey to Kedarnath for the first time, but one person said she had read something about Kedarnath in the well-known comic book series Amar Chitra Katha. We discussed the shape of the linga. I said to me it looked like a mountain. They said one stone is just a stone but this other stone is Shiva, so we worship it as Shiva even though to you it looks like a stone in the shape of a mountain. To us it looks like the back of Shiva or the hump of his buffalo-form. Bhupendra noted that they themselves said they should be seen as both pilgrims and tourists. One yatri said that at the time of puja there is utter concentration/meditation (Hindi: dhyan). When you look at nature, you take its full joy. After that, Bhupendra and I happily had dinner with the group and then went back to the room we shared for the night. There were many days like this.

\section{WEATHER}

The weather is one of the most important constituent factors in how people experience Kedarnath. ${ }^{17}$ The weather in Kedarnath is distinct, even different from the kinds of weather found on most of the path from Gaurikund. It is colder and there is often more fog and precipitation. It snows and hails sometimes, even in the summer. Preparing to visit the temple and waiting in the queue (to say nothing of making the trip from Gaurikund) when the sun is shining and one can gaze on the 
glaciers spread out behind the temple is radically different from waiting with bare feet and usually inadequate rain gear and warm clothing when fog, rain, hail, and sometimes snow descend. Once when I was conversing with a yatra guide from Varanasi as we walked back down to Gaurikund, he confessed that he had not bathed before entering the temple because it was so cold that he simply could not make himself do it. He was comforted by the well-known local idea of the "wind bath" (Hindi: hawa snan). This phrase refers to the idea that the meteorological environment purifies those who enter Kedarnath in a way that that makes actual bathing optional. I heard locals refer to this idea many times. It was an implicit acknowledgment of the difficulties inherent in a high place where the balance of wind, sun, and precipitation was always changing. As with the previous examples, this idea shows how the natural environment exercises a religious power in its own right that is both connected to what is present in the temple (one should be pure to enter the temple) and different from it (the purificatory power arises from the weather and not, in a direct sense, from the presence of Shiva). Since 2013 there has of course been another layer to all of this: the overshadowing memories of 2013 triggered by bad weather.

\section{TENSION}

The excitement of the high season in 2007 and 2008 had many different valences. On the one hand, it functioned as a religious spectacle that celebrated, as Shukla-Ji described in the Introduction, the shakti of the god and the place, and the traditional and at the same time modern power of yatra. On the other hand, the number of people in the place and the amount of money circulation created stressful situations. On May 27, 2007 there was a confrontation between a sadhu (Hindi: renunciant, ascetic) who had been living in the Kedarnath valley for decades and a group of sadhus who he felt were not behaving with proper restraint (Hindi: maryad). It escalated into a physical confrontation that settled down only after the police became involved. The angry sadhu said that some of the resident sadhus were bothering pious yatris who were coming to Kedarnath for darshan and perhaps even stealing from them. These false renunciants, he said, were hoarding their donations for their own use. Instead, he felt, they should be using those funds to give yatris chai to drink and food to eat, and to buy fuel for fires to warm the cold, shivering yatris who found themselves unprepared for the high mountain weather. He said that these false renunciants were making the temple dirty. Yatris were dying from cold, he said, and these sadhus didn't care.

In June a well-known politician visited Kedarnath. As is often the case when such figures visit, he was received by representatives of the Kedarnath Tirth Purohit Association. On his way to the temple the politician was asked to lend his support to the extension of the motor road up to Kedarnath. He said that Kedarnath was a holy place and shouldn't be turned into Switzerland. He pointed to how Gangotri 
(the second of the Four Dhams, near the source of the Ganges River) had become a honeymoon spot, and he referenced a time when his audience's forefathers had had to work in an environment where visitors came up from Rishikesh on foot. After darshan and puja in the temple the conversation continued. The politician said that the government was looking into the impact the number of visitors was having on the rate of glacial melt and that government experts were now considering what sort of development (Hindi: vikas) should happen so that more harm did not come to the environment.

On that day the line was very long, and even though it was well into the afternoon the temple had not yet closed for bhog. There was an uncomfortable amount of tension and confrontation in the temple courtyard between tirth purohits and the Samiti surrounding the question of who, under what conditions, could facilitate access to the inner sanctum of the temple by allowing people to enter through the side door of the temple and not wait in the queue. Tirth purohits wanted to be able to take their important patrons through the side door. I remember that what struck me about this scene was not the confrontations themselves. After all, there are many contexts when matters having to do with long lines and short tempers become confrontational. What I found notable was that, in the half circle of onlookers that surrounded the small nodes of tension there were many pairs of men holding hands as friends do, and each pair consisted of one tirth purohit and one employee of the Samiti. To me, it was an affirmation of the solidarity of local identity (in both groups almost everyone hailed from the Kedarnath valley) against bigger and in many ways translocal pressures of the high season that were pitting them against each other with so much force. The pressures of the business of yatra were changing Kedarnath, and tension-filled moments like this were becoming more common.

\section{LABOR}

Kedarnath in 2007 and 2008 was a place that highlighted the ability of pilgrimage tourism to radically change the economic, cultural, and environmental landscape. In addition to the pilgrimage priests and Samiti employers there were all the people who worked in shops and lodges. A community of cleaners came on contract from Uttar Pradesh each year and lived in Kedarnath. There were employees of the Garhwal Regional Development Authority (Hindi: Garhwal Mandal Vikas Nigam or GMVN) and doctors and nurses who worked in the private clinic and the small public hospital. There were the employees of the helicopter companies. There were the dozens of small chai shops and thousands of rooms for rent between Guptkashi and Kedarnath. There were the employees of the Public Works Department who maintained the road. If one extended the unit of analysis to include the entire Uttarakhand Char Dham and the Sikh pilgrimage destination of Hemkund Sahib, 
then the economic zone affected by Char Dham Yatra tourism would also have to include the entire national highway and rail network between Delhi and Haridwar traveled by most of those on their way to Uttarakhand. The entirety of this built and economic environment rested on the shoulders of those involved with transportation and construction. With the exception of locally grown fruit, vegetables, rice, dal, and wool products, almost everything had to come up into the mountains by truck to somewhere between Guptkashi and Gaurikund. Thence, depending on its final destination, it was carried the rest of the way by men, ponies, and mules from typically either Sonprayag or Gaurikund. The only exceptions to this rule were materials that arrived by cargo helicopter, a rare occurrence that became increasingly common after 2014 with the construction of a new helipad behind Kedarnath that was able take the weight of the cargo helicopters. The inadequacy of the old one was greatly apparent during the rescue and relief operations of 2013, when the waterlogged ground could not take helicopters' weight.

A staggering amount of labor was involved with the delivery of materials to Kedarnath. Often visitors would be aghast at the high prices charged for consumable goods in Kedarnath. While there was a certain degree of price inflation that had to do with a fairly ideal seller's market, much of the inflation was based on how much it cost to get the goods to Kedarnath in the first place. Men, mules, and ponies were also many yatris' means of journeying from Gaurikund to Kedarnath. Small adults and children would often be carried on the back of a single porter, and teams of four men would often carry yatris in a chair slung between two poles that in form greatly resembled the dolis of the devtas. Many of the porters were Nepalis who annually came to Uttarakhand to work during the pilgrimage season. Most of the horse and pony drivers were Kedarnath valley locals. Porters traveling back and forth from Gaurikund to Kedarnath would often make several trips a day, a level of physical exertion that I found difficult to comprehend.

There was also, always, a great deal of construction going all along the motor road in the Kedarnath valley and in Kedarnath as well. The years 2007 and 2008 were a boom time for construction. People were building new rooms and lodges, renovating existing buildings, and adding amenities that would be attractive to middle-class yatris. Friends of mine were deciding against moving down to a city like Dehra Dun and looking for work and instead borrowing money to build a lodge with attached restaurant in a good spot along the Guptkashi-Gaurikund road.

\section{LIVELIHOOD}

Kedarnath had become a place for big business by 2007. This was an important aspect of the feel of the place-the constraint and tension produced by economic 
forces. The following is a close, remembered paraphrase of what a local Kedarnath valley man told me when we were sitting conversing and having chai together in Kedarnath:

Whoever lives in Kedarnath, his first thought is for his livelihood. First livelihood, then Kedarnath. When I was little I used to see [the renunciant] Phalahari Baba, and since then I've never seen any other saint like him. His burial place [Hindi: samadhi] is on the way to the Bhukund Bhairavnath path. He used to live here twelve months out of the year. His sitting place was next to a shop across from the temple, and I along with two or three other boys would go and steal ten-rupee notes from underneath his knees. We used to do this three or four times a day, always in front of others who were sitting with him. Seeing us, they would start to scold because they knew we were coming to steal. Baba used to smile and scold the scolders, saying, "Why are you scolding them and preventing them? What have they done to you? Let them come."

Nowadays whoever is living here, everyone's first priority is money and then Kedarnath. No one can say that I am here for Kedarnath. If anyone says this, they are out-and-out lying. There was once a shepherd who used to live near Vasuki Tal, originally from Himachal. So once I went to Vasuki Tal and drank chai in his hut and he gave me two roti to eat. I became friends with him. And whenever he came down he would always come visit me in Kedarnath at least once for chai and conversation. One day he told me, "I saw an actual [Hindi: sakshat] Kedarnath temple near Vasuki Tal. Puja was happening there exactly in the way that it happens here in Kedarnath." He told me but I didn't believe him. But he was totally certain, with full belief [Hindi: vishvas], that he had seen what he had seen. But one second later nothing was to be seen-it was just a glimpse. So I said, "You have had a vision of Future Kedar [Hindi: Bhavishya Kedar]. In the Kedarakhanda it is written that here there is somewhere a Future Kedar, just as there is a future Badrinath [Hindi: Bhavishya Badri].” When I was once near Vasuki Tal I was in my own devotion singing a bhajan with a soft voice and then with increasing volume. Then a devta came upon a woman who was sitting near there. She started screaming loudly. I saw this, so I thought I should stop singing that, so I stopped.

For yatris this place is heaven, but for us it is a place to earn a living. Also sadhus are coming here for money. If I did not need money, I would come to Kedarnath for a week or so and then leave. It is of course true that there is a great deal of faith [Hindi: shraddha] in Kedarnath because everyone depends on Kedarnath for earning, but where there is livelihood there cannot be [religious] feeling [Hindi: bhav]. When I am thinking about earning it is impossible to relate to Shiva appropriately. While it is true that during Shravan I will go pour water on the linga, I basically do this only because I am there already. I greatly esteem Kedar [Hindi: Kedar ko bahut manta hun], but most of the time when I am here I am thinking about yatris and not my own bhav.

This local man agreed with my perception that all of the development had happened in the last ten to twenty years and especially in the last five or six, but he did not see the development as being connected to the creation of the state. 
He said he had formerly wandered a lot but now could not go up very far from Kedarnath itself. There was something special in Kedarnath, and whenever one left Kedarnath even to go as far as Garud Chatti this peace (Hindi: shanti) was lost. ${ }^{18}$

\section{TREKKERS}

One of the most important ways in which Kedarnath, and indeed the entire landscape of pilgrimage tourism in Uttarakhand in recent decades, had been changing was that it was seeing a marked increase in the number of trekkers and visitors whose primary goal was to walk in the mountains and to raft the rivers. In Kedarnath such visitors were sometimes interested in a half-day jaunt up to Gandhi Sarovar and sometimes were experienced mountaineers keen to walk on a glacier. Most of them used to come up the path from Gaurikund with everyone else. However, on June 14, 2007, three Bengali men and six porters arrived in Kedarnath by foot from the north, along with one renunciant. They had walked over the mountains from Rhansi in the Madmaheshwar valley, two valleys to the east. They said that it had taken them nine days and that they had walked on a glacier for three or four kilometers of the trip and had narrowly escaped death several times. At one point, just after having performed a puja at a local goddess shrine, they heard the sound of a breaking glacier on the other side of the mountain from where they were. Camping by tent, they said that they had come to Kedarnath via the Great Path. On another occasion, a group entered Kedarnath from the north and reported that they were returning from a month-long journey to Kailash Mansarovar. Numerous sightseers would make the short trek up to Gandhi Sarovar or go walking in the side-valleys behind Bhukund Bhairavnath. The occasional parade of groups of trekkers into Kedarnath was part of the melathe difference was that in some cases they explicitly were not in Kedarnath out of bhakti or out of desire to take darshan.

\section{GARHWALI SUPERNATURAL BEINGS}

What non-Garhwalis might see in a relatively high Himalayan landscape differs radically from how such locales are imagined in traditional Garhwali worldviews. The end-valley of Kedarnath is significant in Garhwali religious worldviews for more than the journey of the Pandavas and the presence of Shiva, Devi, and Bhairavnath, as I found out during a monsoon-season chat in Kedarnath. On July 22, 2007, in the month of Ashadh, when Kedarnath was almost at its emptiest and there were many rainy days of chai shop conversation, Bhupendra and I found ourselves in a conversation with the elderly mother of a Kedarnath tirth purohit friend and two of her female friends at his dharamshala. She had been in Kedarnath for a month and planned to stay until the end of Kartik. 


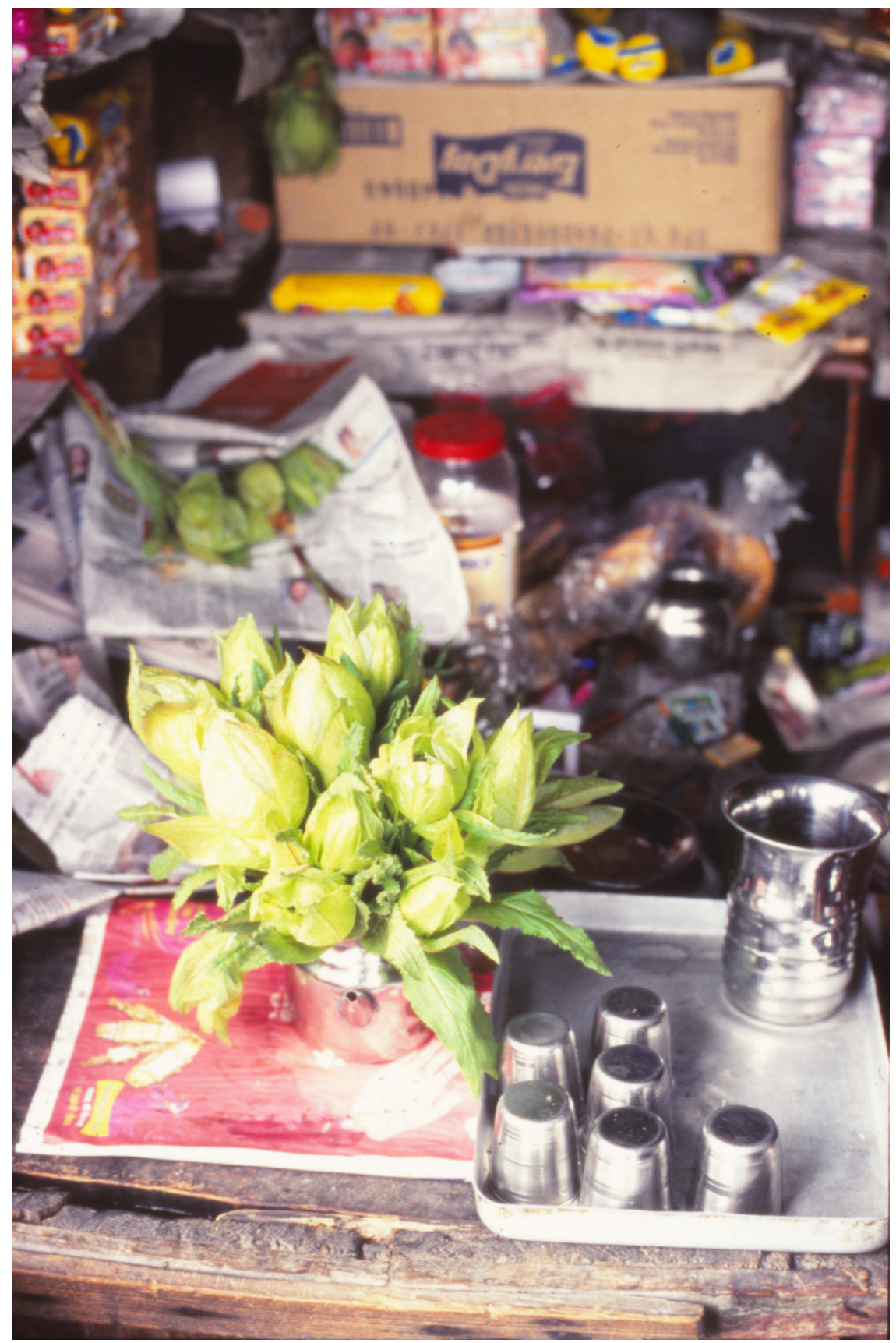

FIGURE 12. A Brahma lotus. 
During the conversation I asked her if Kedarnath and Madmaheshwar were equally important, and she said, as a way of answering, that if women from the Madmaheshwar valley did not sing payari geet, a Garhwali genre of auspicious (Hindi/Garhwali: mangal) songs that greet the deity when it travels to the village, then the god cursed them but that she (as someone from the Kedarnath side) usually sang Garhwali bhajans about Shiva. She knew payari geet for Madmaheshwar but did not want to sing them because we were not in Madmaheshwar's territory. ${ }^{19}$ Garhwali deities are notoriously territorial. She also said that if she sang them in Kedarnath the acheri would come for her. Acheri is a Garhwali term for a class of forest-mountain spirits. In the high places and wooded river banks of Garhwal there is often the possibility that someone will attract the attention of such spirits. For example, the life story of one of the folk heroes of Garhwali literature, Jeetu Bagadval, ends with his being kidnapped by acheris because his lovely flute playing attracted their attention. In the Kedarnath valley it is customary to keep quiet and not wear bright colors when traveling at high altitude for this very reason. She said that once she had gone with a group of women above the Bhairavnath shrine to gather Brahma lotuses (Hindi: brahmakamal). Brahma lotuses grow only above about 4,200 meters and are offered, either fresh or dried, in the Kedarnath temple. When you pick them you must go barefoot, after having bathed and without having eaten. It is a special form of place-specific prasad (Pinkney 2013b). Pilgrimage priests both give the lotuses to their patrons and sell them to others. Everyone was keeping quiet lest they be kidnapped by acheri. Then near a river someone called her name a little loudly and she became sleepy and started to feel strange; she thought that perhaps she was about to be kidnapped. But they came back down near Bhairavnath and called on him for protection and she was fine again.

\section{NATURE AND SHAKTI IN KEDARNATH}

Sometimes, in conversation with both Kedarnath residents and visitors, I would hear a clear distinction made between the place's natural beauty (Hindi: prakritik saundarya) and the power transmitted into the place by Shiva's presence. More common, however, was a complicated explanation that involved the overlap of these two modalities of place-engagement. Here is an example of what I mean.

During the monsoon season the numbers of visitors from the North Indian plains declined markedly and the hectic rhythms of the high season slowed. It became easier to have longer conversations. I had one such conversation with an older man from Bangalore who made his living selling flowers for use in puja. I met him around the time of the Samiti-sponsored recitation of the Shiva Purana on August 22, 2007, just before the Bhatuj festival. I spoke with him in the presence of the tirth purohit owner of the dharamshala. Over the years the two had become 
good friends. The Bangalore yatri said that he had traveled all over India and Nepal and had been coming to Kedarnath since 1983, when it had featured minimal vikas (Hindi: development) and very few people. According to him, most of the changes had happened in the last seven or eight years. Every day when he visited Kedarnath he would walk out behind the temple to the river banks behind Kedarnath village to sit, perform meditation (Hindi: dhyan karna), and occasionally sing devotional songs (Hindi: bhajan) to nature and/or deities, a conflation that he himself made. He had started staying in Kedarnath because he felt a special attraction and because he felt peace (Hindi: shanti). He gave an amazing definition of shanti, explaining that there are two things in Kedarnath-a "magnet power" that attracted people and natural beauty. When the thread (Hindi: tar) of those two things became one with the tar that is inside a person, then the feeling of shanti was produced.

Not everyone experienced this kind of powerful conflation of divine power and natural environment. Some people attested to the opposite. On August 25, 2007, I spoke with a Virashaiva renunciant who had been staying in Kedarnath for some time. He did not find stories about the Pandavas or the practice of ghee malish to be particularly important. He felt positively affected by the natural beauty of the place and said that, as in Rameshvaram (which looks out onto the Indian Ocean on the other end of the subcontinent in the south), he felt as if he were on the edge of heaven. He emphasized that for him the actual Kedarnath linga was not the center of his religious attention because like all Virashaivas he believed that Shiva was actually formless and lingas were simply meditative aids. He directed most of his devotion (Hindi: bhakti) toward the small linga that he wore around his neck (called ishtalinga by Virashaivas) and had been given by his guru. He performed puja of this linga daily, and when he performed puja and meditated it shone for him as he held it in his hand. Kedarnath was of special importance for Virashaivas, he said, because the first guru of the Virashaivas, Ekoramaradhya, first manifested into the world by emerging out of the Kedarnath linga. Another renunciant who spent the entire season in Kedarnath, performing at least 150,000 recitations of the Om Nama Shivaya mantra per day, expressed a similar sentiment to me. He said that he entered the temple more than most sadhus but that even he did not feel a strong necessity to go inside because he was already living in the center of Shivaterrain (Hindi: Shiv-bhumi).

I happened on another hyperarticulate explanation of the distinct power and character of Kedarnath in late September when I met with a group on a visit to Kedarnath with their guru. The guru had come with his followers for a five-day stay. His followers consisted of singles, couples, and families from both India and America who ranged in age from approximately the midtwenties to the midsixties. They picked several different spots (near the helipad, by Bhairavnath, Shankaracharya Samadhi, Phalahari Baba Samadhi) for morning-long sessions of bhajan singing, teaching sermons (Hindi: pravacan), and question-and-answer periods. 
I visited two of these sessions. Most of the group were dressed in trekking gear. During the first session I saw an example of what I would term guru bhakti, or bhakti directed toward the guru. An elderly man sitting near the guru stretched out his arms and, with slants and twists of his torso and movements of his hands, began to tilt into a horizontal position that gradually brought him closer and closer to the guru. Eventually he clung to his guru, shaking, sometimes resting with his head in his lap in great contentment and sometimes hugging him with desperate force. At one point it looked to me as if his joy was so total that he lost bodily control. The guru remained calm throughout, and it appeared to be for him, as for most of the group, a fairly normal occurrence.

The second session I had with the group was behind the Bhukund Bhairavnath shrine. When I arrived around ten in the morning a pravacan was in full swing, mostly in English. The guru was telling the story of Daksha and Sati with an eye toward the moral that one should always respect the saints and deities of all religions and that if you do not then bad things happen. He described some of the other holy places in the Kedarnath area and the special powers and vibrations associated with them. He dwelt on the importance of Mount Kailasa and narrated at length his own spiritual journey, emphasizing that it had been accomplished through bhakti and bhajans and not through yoga and meditation. He was quite clear that those techniques were not his path and that instead it had been through bhakti that Shiva had at times awakened all seven of his chakras in an instant. He described various visions and levels of experience such as the contemplation of a thousand-petaled lotus of light in which each petal is a different color shaped as a triangle, at the center of which would be the deity of one's choice.

He spoke of the necessity to spend as much time and effort striving for God as one does striving for anything else, and said one must be ready to stand before God and answer the question "What have you done for me lately?" Toward the end of his talk he began to answer questions, and the question of language arose. He said that Hindi was the best language for talking about religion, especially the pure Hindi that was descended from Sanskrit, though if he spoke that way no one would understand. He said that Punjabi was not very good in this regard but better than English. He gave the example of the word joy. In English what does joy mean? Nothing. But anand (Hindi: joy, bliss) — that word has a range of important meanings (such as, for example, the idea that reality as a whole is fundamentally made of joy). He then began to sing devotional songs, beginning with an Urdu ghazal that I did not understand, then shifting to Om Namah Shivaya, and finally to Raghupati Raghav, a popular bhajan associated with Mahatma Gandhi that is often popular for its ecumenical message. He then closed his eyes for over ten minutes, during which time tears began to flow from his eyes. Some of his followers followed his example and remained steadfast in their own practice, while others started to put on warmer clothing because fog had started to come up the valley and the temperature was dropping. 
When he came out of his trance and began to walk back down into the village I introduced myself in Hindi. He smiled and patted my shoulder and said he had already heard of me and what did I want to ask him. My question was interrupted by a renunciant who with choked-up voice and propitiatory tone began a tragic story involving a girl, marriage, and money. The guru responded sternly, saying, "My giving you money will not help you." Then he said, "I am Shiva, I am a destroyer and I have come to destroy. I am not Vishnu, I do not take care of people [Hindi: mai phalan nahin karta].” The sadhu become even more emotional, calling the guru Lord (Hindi: Prabhu) and saying that he could not hide anything from him. Several devotees exchanged knowing smiles. Then I asked the guru what he felt was special (Hindi: vishesh) about Kedarnath and how he understood the connection between the land and the god. He replied that God and shakti are available everywhere but the difference is that in Kedarnath (as in three other places: Dwarka, Rameshvaram, and Vishvanath in Varanasi) the shakti is awake (Hindi: jagrut). In Kedarnath looking for shakti is like digging for water in a place where water runs close to the surface. I asked him what he felt about the ritual of puja. He said that rituals such as puja are not intrinsically important; it is the feeling (Hindi: bhav) that is important. This conversation lasted from the shrine of Bhairavnath until we entered the bazaar. His devotees were crowding around him and one was kissing his shoulder. As we arrived at one of the restaurants in the market it was clear that our time was over.

\section{FORESHOCKS}

Looking back on the 2007 season in the aftermath of the 2013 floods, I feel as if there were a series of premonitions, or, to apply a geological term to a set of socio-ecological phenomena, foreshocks that (in retrospect) were leading up to the floods of 2013. I have already sketched something of the social, economic, and ritual tensions generated by the high season. The end of the season saw additional anxieties. Near that time an official from the state forest department arrived in Kedarnath and began to loudly proclaim that Brahma lotuses were being overharvested. As the official strode through the bazaar, Kedarnath locals began to quietly pull out their phones. It was revealed that he was not there in any official capacity. He was trying to line his pockets while he was still able to say that he worked for the state. His aims unveiled, he hurried out of Kedarnath. At the time I was, perhaps naively, a bit confused. No one seemed concerned at all that perhaps people were in fact picking too many Brahma lotuses. Later that day, sitting in his shop, a Kedarnath pilgrimage priest told me that no one was willing to discuss such things in public because privately everyone was worried that the Mandakini would dry up and the place would become uninhabitable. Such concerns were publicly unvoiceable. 
On October 31, just before the end of the season, one of the long-term resident sadhus in Kedarnath who also spent part of the off-season in and around Ukhimath came into the market and started going on loudly about how a ghost was bothering him: that of a local youth who had died in a freak accident while assisting passengers in getting out of the helicopter earlier in the season. He said that the youth "keeps coming to my tent and trying to talk to me, but he speaks in Garhwali and I can't understand him because I'm not Garhwali. I'm leaving early this year." This sadhu, who had been coming to Kedarnath for years, said that he normally stayed until the last day of the season in order to, among other reasons, receive gifts from wealthy yatris (he referred to them as yajmans, patrons) who came annually for the closing puja and ceremonies.

This ghost incident was apparently part of a larger set of occurrences in which the dead youth had been recently pestering people. One man told me that he was often touched, jabbed, and poked at night by ghosts, though another said he walked at night where he wished and did not fear ghosts in the slightest. As it got colder and the season began to wind down, many locals quietly went home a bit earlier than they had in previous years; the presence of the dead youth was one of the reasons cited by those commenting on the early departure of others. As the last resident in the pilgrim rest house where I was staying, I was repeatedly asked whether I was frightened to stay there alone at night. Eventually I did become frightened one night. Other locals told me that they had not seen any ghosts in Kedarnath and felt no fear at all when walking around alone at night or in their rooms.

This occurrence activated a set of memories and tales regarding the Kedarnath of previous decades. Many pilgrimage priests and other locals could recall a time, beginning several decades earlier, when the village of Kedarnath had had far fewer buildings, lodges, electricity, and lights, when latrines had all been outside the boundaries of the village, and when residents had been afraid to venture beyond the lit boundaries of the village for fear of ghosts (Hindi: bhut) and other supernatural beings such as acheri. Even rumors of the appearance of this dead youth made this older Kedarnath seem less in the past, more in the present. It occasioned an active nostalgia of sorts. Yet at the same time it was the modernized, presentday face of Kedarnath in the form of helicopter blades that had created the situation in the first place. The death had not been the result of a flood, a landslide, an earthquake, a bus accident, a fall due to drunkenness, or a lack of timely medical expertise-these were all known possibilities. It was something new, a deadly sign of how the region was changing.

In Garhwal the deceased usually become present and able to communicate through possession, but this was not a standard case. D. R. Purohit, noted scholar of Garhwali folk-life and religion, confirmed my assessment that this case was, in Garhwali eyes, nonstandard. He informed me that normally, in such cases, the 
dead youth would have first signaled his presence by causing someone to weep violently. This would then have required that the ghost be caused to dance (Hindi: bhut nacana). Through this procedure, presided over by a ghadyalya (a particular type of Garhwali ritual specialist) and conducted in the home, the young man would have possessed some individual from his own home (not from Kedarnath, but from his own house) and spoken through him or her. The ghost would then have lamented his own fate and the fate of his dependents (if any) and relatives and would have stated his unfulfilled wishes. This procedure would have been performed every third or fourth year until the dead person was appeased, at which point an image of the ghost would be made and immersed in the marshes and water tanks of Kedarnath. ${ }^{20}$

Thus the way that the dead youth made his presence known was not the way in which he might have been expected to make his presence known. He spoke without being invited to speak. And he appeared in a place unequipped, in a Garhwali sense, to respond to his attempts at communication. In retrospect, this whole occurrence seemed like a premonition of how the pull of Kedarnath was transforming the Kedarnath valley.

\section{ECO-SOCIAL ENTANGLEMENTS}

Looking across these vignettes, one can see a diverse set of vectors-human, nonhuman, material, nonmaterial, organic, inorganic, animate, inanimate, cultural, ecological, divine, devotional, human, economic, natural-that are, recalling Edward Casey's notion of place as that which gathers, pulled together in a set of complex entanglements of increasing intensity. No one factor of human engagement with and experience of the place can be wholly disentangled from others, just as the changing place cannot be disentangled from the human activities involved in the always-emergent changes. In these vignettes, what is inside the temple cannot be wholly separated from, or wholly conflated with, what is outside the temple. In these scenes the effect of the weather overlaps with the effect of economic constraint, both of which add to the shakti of the place/shakti of Shiva in the place, a shakti engaged and imaged through puja, darshan, meditation, singing, bathing, and wandering. This was the Kedarnath I saw in 2007, 2008, and 2011. 